\title{
Cardiospondylocarpofacial syndrome
}

INSERM

\section{Source}

INSERM. (1999). Orphanet: an online rare disease and orphan drug data base.

Cardiospondylocarpofacial syndrome. ORPHA:3238

Cardiospondylocarpofacial syndrome is characterized by mitral insufficiency, conductive deafness, short stature, and skeletal anomalies (bony fusion involving the cervical vertebrae, the ossicles, and the carpal and tarsal bones). It has been described in three members of one family. The mode of inheritance is likely to be autosomal dominant with incomplete penetrance. 